\title{
Nursing Approach Based on Watson's Theory of Human Caring in Treatment Adherence in Hemodialysis Patients
} Hemodiyaliz Hastalarında Tedaviye Uyumda Watson İnsan Bakım Kuramına
Dayalı Hemşirelik Yaklaşımı

(i) Şefika Tuğba YANGÖZ, id Zeynep ÖZER

Akdeniz University Faculty of Nursing, Department of Internal Medicine Nursing, Antalya, Turkey

\begin{abstract}
Hemodialysis is the most common renal replacement therapy in the treatment of chronic kidney disease. Adherence to treatment is important in hemodialysis which is a complex treatment process. Adherence to treatment includes fluid intake, diet, drug management and participation in dialysis sessions. In hemodialysis patients, many problems may arise due to nonadherence to treatment. Watson's Theory of Human Caring (THC) is the one of the important theories used to understand these problems and adaptation difficulties and to develop appropriate coping methods. Watson's THC enables individuals to be evaluated in a holistic manner, adapt to the disease and treatment process, and recover. This review, which was prepared as a result of the literature review, was prepared to raise awareness about nursing care based on Watson's THC in ensuring compliance with treatment in individuals undergoing hemodialysis therapy.
\end{abstract}

Keywords: Compliance, nursing, renal dialysis, Watson's Theory of Human Caring

\section{ÖZ}

Hemodiyaliz, kronik böbrek hastalığının tedavisinde en sık uygulanan renal replasman tedavisidir. Karmaşık bir tedavi süreci olan hemodiyaliz yönteminde bireylerin tedaviye uyumu önemlidir. Tedaviye uyum süreci ise sıvı alımı, diyet, ilaç yönetimi ve diyaliz seansına katılımı içermektedir. Hemodiyaliz uygulanan bireylerde tedaviye uyumsuzluğa bağlı birçok sorun ortaya çıkabilmektedir. Bu sorunların ve uyum güçlüklerinin anlaşılması ve uygun başetme yöntemlerinin geliştirilmesi için yararlanılan önemli kuramlardan biri de Watson' ın İnsan Bakım Kuramı'dır (THC). Kuram bireylerin bütüncül olarak değerlendirilmesini, hastalık ve tedavi sürecine uyumunu ve iyileşmesini sağlamaktadır. Literatür taraması sonucu hazırlanan bu makale, hemodiyaliz tedavisi uygulanan bireylerde tedaviye uyumun sağlanmasında Watson'ın THC üzerinde temellendirilmiş hemşirelik bakımına ilişkin farkındalık oluşturmak amacıyla hazırlanmıştır.

Anahtar Sözcükler: Uyum, hemşirelik, hemodiyaliz, Watson İnsan Bakım Kuramı

\section{Introduction}

Chronic kidney disease (CKD) is an important health problem that continues to increase in the world and in our country. The World Health Organization's report, published in 2018, stated that 1.2 million individuals died from kidney disease in 2015, and that an estimated 2.3-7.1 million people with end-stage kidney disease died without access to chronic dialysis in 2010, and that mortality has increased by $32 \%$ since 2005 . In the same report, it was reported that 2.1 million individuals received dialysis treatment in 2010 and that by 2030, individuals receiving dialysis treatment would reach double that (1). In our country, according to the Turkish Nephrology Society's 2017 report, the prevalence of end-stage kidney disease requiring renal replacement therapy (RRT) was 956.7 per million population, 77,311 individuals 
received RRT and the most frequently administered RRT was hemodialysis therapy (76\%) (2).

The hemodialysis method involves a complex treatment process and it is important that individuals adapt to the treatment. The process of adaptation to treatment in hemodialysis method includes diet, fluid intake, drug management, participation in dialysis sessions and completion of Sessions (3). Due to the adaptation problems experienced by individuals, hemodialysis treatment and the problems that can be seen due to the treatment; the individuals have problems in terms of physical, mental and socioeconomic aspects and their quality of life is negatively affected $(4,5)$.

Understanding of individuals' disease behavior, psychological responses and adaptation difficulties and implementing holistic care initiatives to support the development of appropriate coping methods are needed. To provide this, nursing-specific theories and models are used as guides (6). One of the important theories used in nursing is the Watson' Theory of Human Caring (THC). Watson based his theory on the view that humans cannot be treated as objects, nor can they be separated from their own selves, from other people, from nature and the universe. THC is seen as a philosophical and moral basis for professional nursing $(7,8)$.

This review is intended to raise awareness of nursing approaches based on Watson's THC in ensuring compliance with treatment in patients undergoing hemodialysis therapy.

\section{Adaptation to Treatment in Individuals Undergoing Hemodialysis Therapy}

Hemodialysis is the most common and safe treatment method among renal replacement treatments, providing fluid electrolyte balance, homeostasis, normal plasma $\mathrm{pH}$ and removal of nitrogenous waste products from the body (9). However, individuals' compliance with diet, fluid intake and drug management and participation in dialysis sessions affect the success of the treatment process (10). Failure to adapt to treatment leads to increased complications, morbidity and mortality $(11,12)$.

Incompatibility with fluid intake is one of the most common problems in individuals undergoing hemodialysis therapy. Rate of incompatibility with fluid intake was found in the international literature as $22-77 \%(13-16)$ and in our country as $60-95 \%$ (1719). Excessive fluid intake causes shortness of breath, headache, abdominal distension, edema, hypertension and heart failure (20). It also causes disorders in cognitive functions, an increase in hospitalization and mortality (11).

Individuals are required to adapt to the intake of many components such as calories, sodium, protein, potassium, phosphorus, calcium in their diet (21). Non-compliance with dietary intake was found in the international literature at rates of $41-84 \%$ $(13,16,22,23)$ and in our country at rates of $64-98 \%(18,19)$. Incompatibility in each dietary component causes different problems in individuals. The lack of compliance with sodium intake leads to excessive fluid intake and associated increase in total body fluid and interdialytic weight; incompatibility in phosphorus uptake leads to disorders in mineral metabolism and cardiovascular diseases; incompatibility in potassium uptake leads to arrhythmias and increase in mortality; incompatibility in protein uptake leads to complications and increase in mortality due to increase in urea (24-26).

Non-compliance with the treatment regime can be seen as deliberate incompatibility in the form of changing, delaying or skipping medication doses, or as non-intentional incompatibility in the form of forgetfulness, lack of information or lack of communication. In the literature, incompatibility with drug intake was found to be $22-56 \%$. Non-compliance with drug intake in individuals leads to an increase in complications, mortality and hospitalization $(27,28)$.

Participation in hemodialysis sessions and completion of sessions are important in removing waste materials and fluid from the body. Failure to attend a single session leads to a 1.4-fold increase in hospitalization rate and a 2.2 -fold increase in mortality in individuals within 30 days (29). In the literature, incompatibility to session attendance or shortened session rate was found to be $7-32 \%(29-31)$.

By properly addressing individuals experiencing non-compliance problems, improving participation and compliance awareness in diet and fluid restriction, drug management and dialysis sessions will contribute to improving the quality of life of individuals by reducing the risk of complications. It is emphasized that the role of health professionals is important in this change $(14,32)$. It is the nursing theories that will guide these initiatives of nurses. Nursing theories provide systematic presentation of the care given (6). One of the important theories utilized in nursing care is the Watson's THC.

\section{The Conceptual Framework of the Watson's Theory of Human Care}

The Watson's THC is a theory focusing on transpersonal relationships and life experiences developed by Jean Watson from 1975-1979. Watson's theory states that nursing care should be humane, conscious and purposeful. In theory, nursing is defined as helping the individual achieve high harmony within the mind, body and spirit, and it is stated that this harmony can be achieved through care interactions involving transpersonal care relationship $(6,7,33)$. The theory consists of three components: (a) the caritas processes, (b) the transpersonal caring relationship, and (c) the caring occasion or caring moment (7).

The theory is widely used in nursing applications. According to Watson, nursing care is not traditional nursing practice. The nurse should focus on the physical needs of the individual as well as the integrity of mind and spirit. "Care is the heart of nursing" and is a must for patients, families, communities and the entire universe. The nurse communicates transpersonal communication while giving care and a vital consciousness is formed when care is given by the nurse and taken by the patient $(7,34)$. 


\section{Transpersonal Caring Relationship}

Transpersonal care relationship is defined as establishing a special communication between the nurse and the individual in the process of care, improvement, or authentic relationship that involves connecting and adopting each other's spirit. The transpersonal care relationship seeks for deeper sources of internal healing as well as leading to cure illness or problems. Traditional nursing practices turn into conscious and professional nursing practices when authentic relationship is established with improvement processes. Both the patient and the nurse are in recovery process $(8,34)$.

In the interpersonal care relationship, the nurse establishes a sincere, trustworthy, natural, loving and conscious authentic relationship with the patient, which includes mimics, colors, emotions and words. In order for care to begin, the nurse must enter the existential space of the individual. The individual's existential space consists of his/her thoughts, goals, expectations, needs, feelings and spiritual needs and is unique to the individual (6). The following examples of questions are suggested in order to reach the existential domain of the individual.

- Can you talk about yourself?

- Can you talk about your experiences in life?

- Can you talk about what you feel physically?

- Can you talk about your spiritual and cultural beliefs?

- Can you talk about your goals and expectations? (6).

In the transpersonal care relationship, the nurse provides the strengthening of the individual's state of well-being, increasing the harmony and comfort of the individual by reaching the existential area of the individual $(6,8)$.

\section{The Caring Occasion or Caring Moment}

The state of care is the ability to interact between the nurse and the individual's life stories and phenomenal fields at the moment of giving care to the individual. The phenomenal field of the individual is defined as life experiences consisting of thoughts, expectations, feelings, beliefs, bodily perceptions and environmental factors $(6,8)$.

According to Watson, at the time of care the nurse and the individual have an opportunity to present their life stories and phenomenal fields when they come together. Communication established at the time of care transcends time and space, reaching a deeper level than physical interaction. It enables the individual to be satisfied with care and to strengthen the healing process $(7,8)$.

\section{The Caritas Processes}

The caritas processes were developed by Watson in 1979 and revised by her in 1985 and 1988 and were described as the essence of nursing. Processes include the concepts of value, love, appreciation. Nurses must internalize and adopt these concepts in their approach and care to the individual. There as 10 caritas processes $(6,7)$ :

- Values system of humanism and dedication

- Faith - hope vaccination

- Sensitivity to self and others

- Helpful and reassuring caring relationship

- Expressing positive and negative emotions

- Creative problem solving in caring process

- Individual learning-teaching

- Supportive, protective and/or corrective mental, physical, social and spiritual environment

- Helping people’s needs

- Existential-phenomenological-spiritual forces (8).

The cavitas processes are the guide to nursing initiatives and constitute the science, art and philosophy of nursing care. Processes are related to each other, all processes can be used together or can be applied separately. In the care given through the caritas processes, the individual is treated as a whole which reinforces the individual's well-being and harmony $(6,35)$.

\section{Nursing Care Based on Watson's Theory of Human Care in Patients Undergoing Hemodialysis}

Nursing care based on Watson's THC in patients undergoing hemodialysis is expected to support the process of adaptation to treatment including diet, fluid restriction, drug management and participation in dialysis sessions by establishing transpersonal care relationship and to increase their well-being and quality of life by supporting spirituality, which is one of the important elements of the theory, and to strengthen them psychosocially. In Watson's THC, nursing is centered on helping the individual achieve a higher level of harmony within the mind, body and soul, and it is emphasized that this harmony can be achieved through care interactions involving transpersonal care relationships (33).

\section{Establishment of Transpersonal Care Relationship and Initiation of Caring Moment}

The establishment of a reassuring, respectful, sensitive and intimate transpersonal communication with the individual enables the individual to express his/her problems that he or she has experienced during the disease and his/her anxiety and stress about non-compliance with the treatment. In addition, transpersonal care relationship produces mind-body-spirit harmony between the care taker and the giver and provides an energy during the caring moment (7).

Authentic relationship and healing environment concepts are important elements of the theory (6). The authentic relationship between the nurse and the individual in the transpersonal care relationship and at the caring moment makes it easier for the individuals to understand and express their feelings, thoughts 
and needs. In the authentic relationship, the nurse should focus not only on the individual's illness or problem, but on care, healing and wholeness $(7,8)$.

The healing environment ensures that the individual is physically, emotionally and spiritually comfortable and peaceful in all physical and non-physical environments. The environment in which caring is given, should be regulated as a healing environment. For example, the physical environment should be created as clean, comfortable and reliable; and the emotional environment should be specific to the individual and should be created according to the wishes of the individual; while the spiritual environment should be created according to what the individuals want to do according to their beliefs $(7,34)$.

\section{The Caritas Processes}

The caritas processes are the first concept of the THC. Processes are implemented throughout the caring and recovery process. The cavitas processes enable the nurse and the individual to be creative in solving problems (8).

\section{Values System of Humanism-dedication}

Care is based on universal humanistic values. These values are tolerance, empathy, love for oneself and others, and begin with childhood experiences, are developed through faith, culture and art. Devotional values are defined as the satisfaction we receive from the value we give ourselves. Adopting these values enables us to approach the individual and ourselves with love, compassion and tolerance. It also forms the basis of human care and provides professional care. It constitutes the first and most fundamental factor for science and care ethics $(6,8)$. In this caritas process, it is important to listen effectively to the individual, to pay attention to privacy at the time of data collection, transpersonal communication and care, to accept the individual as he/she is, to respect, to honor the person's values and abilities.

\section{Instilling Faith and Hope}

The process of instilling hope and belief is to know the feelings, thoughts and beliefs that the individual experiences in his or her inner world and to instill positive and promising thoughts and words. The belief of the individual is supported, honoured, and in this way it is ensured that the individual improves and sustains his or her health $(7,34)$. In this cavitas process; the individual should be seen not as an object but as a human being; the individual should be addressed by name, eye contact and touched; the individual should be helped to believe in herself/ himself, and the hope should be supported $(8,33)$.

For example;

- The nurse should talk with the individual about the positive and negative developments in hemodialysis treatment and adaptation process, support the positive aspects of faith-hope and try to strengthen them.

- In the next process, the individual should be informed that communication can be established.

\section{Being Sensitive to Self and Others}

Most of the time people don't want to express their feelings. In order to develop sensitivity to oneself and other people, the individual needs to recognize and feel their emotions. Nurses can recognize and encourage others to do so if they feel their own feelings. Being sensitive to individuals who are sick, especially in nursing, makes the individual comfortable and allows us to support the healing process and show that we are on the side of the individual $(6,36)$. In this caritas process, we should be more sensitive to the needs and feelings of the individual, showing that we are willing to explore the feelings, beliefs and values of the individual $(7,8)$.

For example;

- The individual should be asked about the positive/negative experiences in his/her life and how he/she copes with the negative situations he/she has experienced and the individual should be asked to talk about his/her experiences during the time he/she is diagnosed as having chronic kidney failure and undergoes hemodialysis treatment.

- It should be ensured that the individual shares his/her feelings and thoughts about the process of adaptation to treatment and about his/her later life.

\section{Development of Helpful-reassuring Relationship}

The caring relationship is an transpersonal process, and in this process it is important to respect the individual, to make the individual feel that we are listening to him/her, to connect with the individual's soul that goes beyond physicality. Development of helpful and reassuring relationship enables the individual to feel safe and reduce incompatibility issues $(7,37)$. In this caritas process, unconditional love and respect should be shown to the individual, non-judgmental attitudes should be displayed. The nurses should be honest, sincere, sensitive and open in communication and should allow the individual to choose the best time to talk about his/her concerns $(7,8)$.

For example;

- Individuals should be supported to talk about their problems with fluid restriction, diet, drug management and dialysis sessions.

\section{Encouraging the Individuals to Express Their Positive and} Negative Emotions and Accepting Them

Thoughts, behaviors and experiences need to be considered and accepted in the human care process. In the caritas process, the care relationship becomes deeper, more honest, and more authentic if the nurses focus on the feelings of the individuals and understand them. Also, listening to and honoring the feelings of individuals are important for the individual's healing and harmony $(8,35)$. During this caritas process, the individual should be encouraged to express himself/herself and supported to reflect his/her feelings and experiences. Praying and spiritual relief should be offered, the individual should be helped to see the good aspects of his/her situation, the individual should be accepted and supported to cope with negative emotions $(6,7)$. 
For example;

- The individual should be asked to express his/her feelings and thoughts about the disease process and the individual should be asked questions

- Can you tell me what you went through during that illness?

- What are the symptoms of chronic kidney failure and do you have any difficulties about it?

- How did that illness affect your social life?

- What do you think it means to adapt to disease and treatment?

- The individual should be asked to express their fears about the disease process.

- Can you talk about your fears about your illness? What does frighten you during the disease process?

\section{Systematic Use of Scientific Problem Solving Method in Caring Process}

Professional nursing is to use problem solving methods and a creative approach in the nursing process. This process includes information, technology, skills, instincts, ethics and personal information. It is suggested to be in a scientific, systematic, logical framework and to use technology when giving care $(34,38)$. In this caritas process, the individual should be encouraged to ask questions. A healing environment should be created: Sound, authenticity, artistic expression, art therapy, keeping a diary, game, humour, fun, spontaneity, music, readiness, breathing, relaxation, daydreaming, imagination, and volunteering, eye contact, smile, positive attitude, active listening, light and noise protection should be regarded as effective elements in the planning of care $(7,8)$.

For example;

- The individual should be educated about the importance of diet, fluid control, drug compliance and participation in dialysis sessions.

- The individual should be encouraged to speak and ask questions.

- Is there a question you would like to ask me about fluid restriction, diet and drug management or anything?

\section{Promoting Transpersonal Teaching-learning}

It involves learning and teaching according to the individual's needs and understanding method when an individual needs information. The role of nurses in education is focused solely on providing information. In this process, an appropriate, friendly learning and teaching environment is created with the individual, providing self-learning, self-coaching, healing and harmony $(8,39)$. In this caritas process, cooperation should be made with the individual, calm and respectful conversation should be made with the individual, the individual's readiness to learn and knowledge level should be evaluated, the individual should be helped to express his/her concerns and questions to health workers $(6,35)$.
For example;

- The individuals should be asked about their experiences and knowledge about fluid restriction, diet, drug management and dialysis sessions.

- Can you tell me what you're doing with that fluid restriction, diet, drug management and dialysis sessions?

- Can you tell me a little bit about your relationship with that fluid intake?

- Can you tell me a little bit about your relationship with that diet management?

- Can you tell me about your relationship with those drugs?

- Can you tell me a little bit about your dialysis sessions?

- The individual can be encouraged to speak and ask questions.

Providing a Supportive, Protective Physical, Sociocultural and Spiritual Environment

The purpose of creating such an environment is to provide quality care and to ensure recovery. A comfortable, clean, aesthetic, private and safe environment needs to be created. Creation of a healing environment promotes the use of improvement, adaptation and caring methods. For example, applications such as imagery, visualization, relaxation, music, touch, art are utilized to create a healing environment $(6,40)$. In this caritas process; space must be created to establish a relationship with the individual, the individual must rest carefully, the needs of the individuals must be predicted in advance, and their routines and rituals must be learned $(8,39)$.

For example;

- A physically, emotionally and spiritually comfortable and healing environment should be created.

- The privacy of the individual should be protected during the hemodialysis treatment process.

- The individual must express himself/herself.

- The individual's problems related to hemodialysis and adaptation to treatment should be tried to be corrected.

\section{Helping People's Needs}

To help individuals meet their physical, emotional and spiritual needs. During the caritas process, not only the physical needs must be met, but the individual's soul must also be touched. All needs are linked to each other, and all needs for the caring-healing process are equally important and valuable $(8,41)$. In this caritas process; the individual should be evaluated in a holistic way and be helped to meet his/her needs. The individuals' needs should be respected. The nurses should be sensitive to the individual's family and loved ones, and ensure the participation of family and other important persons $(7,34)$. 
For example;

- Is there a question you would like to ask me about fluid restriction, diet, drug management and dialysis sessions or anything?

\section{Existential-phenomenological-spiritual Powers}

It incorporates the mystique, philosophy, and metaphysical aspects of human experiences and phenomena that do not conform to traditional science. It consists of belief systems of the individual, the family and the nurse that express the meaning of life and death. This belief system includes cultural beliefs, myths and metaphors $(8,42)$. In this caritas process, miracles should be allowed to happen for the individual, the individual's hope should be supported and nurtured, the individual's feelings should be accepted, and what is important for the individual should be known $(6,36)$.

For example;

- The individual should be able to share feelings and thoughts about the hemodialysis treatment process and adaptation process.

- The spiritual needs of the individual should be respected and supported.

\section{Conclusion}

Watson's THC is a model that provides the application of nursing care within love, respect, compassion and trust, which assesses the individual in mind-body-spirit harmony, which ensures that not only the physical needs of the individuals but also their emotional and spiritual needs are met. Individuals undergoing hemodialysis treatment encounter many negative factors during the disease and treatment process. Adaptation to hemodialysis treatment in individuals is an important process, and Watson's THC is an effective and easy to implement theory in dealing with these adversities and adaptation problems. The theory ensures that individuals are evaluated on a holistic basis and that individuals are given care after that, and thus, individuals' recovery, compliance with the disease and treatment process and satisfaction are increased.

It is proposed to use Watson's THC as a guide in creating the conceptual framework of nursing care, and to apply and evaluate the model in different disease groups.

\section{Ethics}

Peer-review: Externally peer reviewed.

\section{Authorship Contributions}

Concept: Ş.T.Y., Z.Ö., Design: Ş.T.Y., Z.Ö., Data Collection or Processing: Ş.T.Y., Z.Ö., Analysis or Interpretation: Ş.T.Y., Z.Ö., Literature Search: Ş.T.Y., Z.Ö., Writing: Ş.T.Y., Z.Ö.

Conflict of Interest: No conflict of interest was declared by the authors.

Financial Disclosure: The authors declared that this study received no financial support.

\section{References}

1. Luyckx VA, Tonelli M, Stanifer JW. The global burden of kidney disease and the sustainable development goals. Bulletin of the World Health Organization 2018;96:414.

2. Süleymanlar G, Ateş K, Seyahi N. [Registry of The Nephrology, Dialysis And Transplantation in Turkey-Registry 2017]. Türk Nefroloji Derneği Yayınları, Ankara. 2017.

3. Ok E, Kutlu FY. Hopelessness, Anxiety, Depression and Treatment Adherence in Chronic Hemodialysis Patients. International Journal of Caring Sciences 2019;12:423-9.

4. Ibrahim S, Hossam M, Belal D. Study of non-compliance among chronic hemodialysis patients and its impact on patients' outcomes. Saudi Journal of Kidney Diseases and Transplantation 2015;26:243.

5. Mukakarangwa MC, Chironda G, Bhengu B, Katende G. Adherence to Hemodialysis and Associated Factors among End Stage Renal Disease Patients at Selected Nephrology Units in Rwanda: A Descriptive Cross-Sectional Study. Nursing research and practice 2018;2018.

6. Smith MC, Parker ME. Nursing theories and nursing practice. Fourth Edition ed. Philadelphia, America: FA Davis; 2015.

7. Watson J. Human Caring science. A theory of Nursing Second Edition ed. Burlington, MA: Jones \& Barlett Learning; 2012.

8. Watson J. Unitary Caring Science: Philosophy and Praxis of Nursing: University Press of Colorado; 2018.

9. Grossman S. Acute Renal Injury and Chronic Kidney Disease. In: Grossman S, Porth CM, Conelius J, Gerard SO, Moriber N, O’Shea ER, et al., editors. Porth's pathophysiology: Concepts of altered health states. 9th Edition ed. Philadelphia, PA: Wolters Kluwer Health | Lippincott Williams \& Wilkins.; 2014. p. 1112-31.

10. Lins SMdSB, Leite JL, Godoy Sd, Tavares JMAB, Rocha RG, Silva FVC. Treatment adherence of chronic kidney disease patients on hemodialysis. Acta Paulista de Enfermagem 2018;31:54-60.

11. Naalweh KS, Barakat MA, Sweileh MW, Al-Jabi SW, Sweileh WM, Sa'ed HZ. Treatment adherence and perception in patients on maintenance hemodialysis: a cross-sectional study from Palestine. BMC nephrology 2017;18:178.

12. Tohme F, Mor MK, Pena-Polanco J, Green JA, Fine MJ, Palevsky PM, et al. Predictors and outcomes of non-adherence in patients receiving maintenance hemodialysis. International urology and nephrology 2017;49:1471-9.

13. Beerendrakumar N, Ramamoorthy L, Haridasan S. Dietary and fluid regime adherence in chronic kidney disease patients. Journal of caring sciences 2018;7:17.

14. Edison C. Adherence to dialysis therapy management in hemodialysis patients. UI Proceedings on Health and Medicine 2018;3.

15. Jampour L, Dehzad S, Eftekhari MH, Akbarzadeh M. The Evaluation of Adherence to Dietary and Liquid Intake Recommendations in Hemodialysis Patients. International Journal of Nutrition Sciences 2018;3:92-8.

16. Khalil AA, Darawad MW. Objectively measured and self-reported nonadherence among $\mathrm{J}$ ordanian patients receiving hemodialysis. Hemodialysis International 2014;18:95-103. 
17. Efe D, Kocaoz S. Adherence to diet and fluid restriction of individuals on hemodialysis treatment and affecting factors in Turkey. Japan journal of nursing science: JJNS 2015;12:113-23.

18. Korkmaz Y. Evaluation of the hemodialysis patients' self- efficacy, adherence and non-adherence to treatment and fluid restriction [Master's]. AnkaraTurkey: Başkent University; 2016.

19. Mollaoğlu M, Kayataş M. Disability is associated with nonadherence to diet and fluid restrictions in end-stage renal disease patients undergoing maintenance hemodialysis. International urology and nephrology 2015;47:1863-70.

20. Wong M, Ghebleh P, Phillips S. Tips for Dialysis Patients With Fluid Restrictions. Journal of Renal Nutrition 2017;27:e35-e8.

21. Lambert K, Mullan J, Mansfield K. An integrative review of the methodology and findings regarding dietary adherence in end stage kidney disease. BMC nephrology 2017;18:318.

22. Ahrari S, Moshki M, Bahrami M. The Relationship Between Social Support and Adherence of Dietary and Fluids Restrictions among Hemodialysis Patients in Iran. Journal of caring sciences 2014;3:119.

23. Chironda G, Bhengu B. Engagement with Fluid and Dietary Restriction among Chronic Kidney Disease (CKD) Patients in Selected Public Hospitals of KwaZulu-Natal (KZN) Province, South Africa. Health Science Journal 2016;10:1.

24. Beerappa H, Chandrababu R. Adherence to dietary and fluid restrictions among patients undergoing hemodialysis: An observational study. Clinical Epidemiology and Global Health. 2018.

25. Umeukeje EM, Mixon AS, Cavanaugh KL. Phosphate-control adherence in hemodialysis patients: current perspectives. Patient preference and adherence 2018;12:1175.

26. Ko GJ, Obi Y, Tortoricci AR, Kalantar-Zadeh K. Dietary protein intake and chronic kidney disease. Current opinion in clinical nutrition and metabolic care 2017;20:77.

27. Ahlawat R, Tiwari P, D'Cruz S. Prevalence and predictors of medication non-adherence in patients of chronic kidney disease: Evidence from a cross sectional study. J Pharma Care Health Sys 2016;3:2376-0419.

28. Ghimire S, Castelino RL, Jose MD, Zaidi STR. Medication adherence perspectives in haemodialysis patients: a qualitative study. BMC nephrology 2017;18:167.

29. Gray KS, Cohen DE, Brunelli SM. In-center hemodialysis absenteeism: prevalence and association with outcomes. ClinicoEconomics and outcomes research: CEOR 2017;9:307.

30. Obialo C, Zager PG, Myers OB, Hunt WC. Relationships of clinic size, geographic region, and race/ethnicity to the frequency of missed/ shortened dialysis treatments. Journal of nephrology 2014;27:42530.

31. Nicholas SB, Kalantar-Zadeh K, Norris KC. Socioeconomic disparities in chronic kidney disease. Advances in chronic kidney disease 2015;22:6-15.

32. Ghimire S, Castelino RL, Lioufas NM, Peterson GM, Zaidi STR. Nonadherence to medication therapy in haemodialysis patients: a systematic review. PloS one 2015;10:e0144119.

33. Suliman WA, Welmann E, Omer T, Thomas L. Applying Watson's nursing theory to assess patient perceptions of being cared for in a multicultural environment. Journal of Nursing Research 2009; 17:293-300.

34. Lukose A. Developing a practice model for Watson's theory of caring. Nursing Science Quarterly 2011;24:27-30.

35. Costello M. Watson's Caritas Processes ${ }^{\circledR}$ as a Framework for Spiritual End of Life Care for Oncology Patients. International Journal of Caring Sciences 2018;11:639-44.

36. Davidson AW, Ray MA, Turkel MC. Nursing, caring, and complexity science: For human environment well-being: Springer Publishing Company; 2011.

37. Helming MB. Relationships. In: Dossey BM, Keegan L, editors. Holistic nursing: A handbook for practice: Jones \& Bartlett Publishers; 2013. p. 439-62.

38. Bolima DC, Estes T. The Sixth Caritas Process ${ }^{\oplus}$ Use Creative Scientific Problem-Solving Methods for Caring Decision Makingand Creative Solution-Seeking. In: Kathleen S, Jean W, editors. Caring Science, Mindful Practice. New York: Springer Publishing Company; 2018. p. 119-34.

39. Clark C. Watson's human caring theory: Pertinent transpersonal and humanities concepts for educators. Humanities 2016;5:21.

40. İlkay Arslan Özkan, Okumuş H. [A Model Where Caring and Healing Meets: Watson's Theory of Human Caring]. Turkish Journal of Research \& Development in Nursing 2012;14:61-72.

41. Swartley N, Caron SJ. The Ninth Caritas Process ${ }^{\oplus}$ : Assist With Basic Physical, Emotional, and Spiritual Human Needs. In: Kathleen S, Jean W, editors. Caring Science, Mindful Practice. New York: Springer Publishing Company; 2018. p. 167-82.

42. Laws D, Beck MD. The Tenth Caritas Process ${ }^{\oplus}$ : Open to Mystery and Allow Miracles to Enter. In: Kathleen S, Jean W, editors. Caring Science, Mindful Practice. New York: Springer Publishing Company; 2018. p. 183-96. 